\title{
Association between a single nucleotide polymorphism of the $X R C C 1$ gene and hepatocellular carcinoma susceptibility in the Chinese Han population
}

\author{
X.F. Li, Y.X. Chen, W.W. Ye, X.F. Tao, J.H. Zhu, S. Wu and L.Q. Lou \\ Department of Infectious Diseases, the Yiwu Central Hospital, \\ Yiwu, Zhejiang Province, China \\ Corresponding author: L.Q. Lou \\ E-mail: lianqinglou@sina.com
}

Genet. Mol. Res. 13 (1): 160-166 (2014)

Received March 28, 2013

Accepted November 5, 2013

Published January 10, 2014

DOI http://dx.doi.org/10.4238/2014.January.10.7

\begin{abstract}
The human X-ray repair cross-complementing protein 1 (XRCC1) gene is a potentially gene determining hepatocellular carcinoma (HCC) susceptibility. The purpose of this study was to evaluate the association between $X R C C 1$ and susceptibility to HCC. The association of $X R C C 1$ polymorphisms with HCC susceptibility was investigated in $460 \mathrm{HCC}$ patients and 463 controls using the created restriction site-polymerase chain reaction method. Our results indicate that the c.1471G $>$ A variant could be detected and that the allele and genotype frequencies were statistically different between cases and controls. The AA genotype was strongly associated with increased HCC susceptibility as compared with the GG wild genotype $\left(\mathrm{OR}=2.214,95 \% \mathrm{CI}=1.493-3.283, \chi^{2}=15.97, \mathrm{P}<0.0001\right) . \mathrm{In}$ addition, significantly increased $\mathrm{HCC}$ susceptibility was also found in a dominant and recessive model $(\mathrm{P}<0.01)$. The allele A could contribute to $\mathrm{HCC}$ susceptibility compared with the $\mathrm{G}$ allele $(\mathrm{OR}=1.480,95 \% \mathrm{CI}$ $\left.=1.224-1.789, \chi^{2}=16.44, \mathrm{P}=0.0001\right)$. Results from this study indicate
\end{abstract}


that the XRCC1 c.1471G>A polymorphism is associated with $\mathrm{HCC}$ susceptibility in the Chinese Han population. Future studies on larger populations are essential to confirm this association.

Key words: Hepatocellular carcinoma; $X R C C 1$ gene; Single nucleotide polymorphism; Molecular marker; Susceptibility

\section{INTRODUCTION}

Hepatocellular carcinoma (HCC) is the fifth most common cancer and the third leading cause of cancer-related deaths globally (Llovet et al., 2003; Parkin et al., 2005; Parikh and Hyman, 2007). More than 600,000 people die from HCC each year, and $>75 \%$ of these cases occur in the Asia-Pacific region (But et al., 2008; Yuen et al., 2009). China has a very high HCC incidence, where it is the second leading cause of cancer deaths since the $1990 \mathrm{~s}$ (Chen et al., 2010), and it accounts for approximately 55\% of new HCC cases worldwide (Parkin, 2001; Parkin et al., 2005; Schutte et al., 2009). To date, the mechanism of hepatocarcinogenesis remains poorly understood. There are indications in the literature that the human X-ray repair cross-complementing protein 1 (XRCC1) gene may influence the risk of HCC (Rossit et al., 2002; Yu et al., 2003; Chen et al., 2005; Kirk et al., 2005; Borentain et al., 2007; Long et al., 2006, 2008; Kiran et al., 2009a,b; Liu et al., 2011; Pan et al., 2011; Han et al., 2012; Li et al., 2012). Several studies proved that XRCC1 polymorphisms, such as Arg194Trp, Arg280His and Arg399Gln, were associated with HCC (Rossit et al., 2002; Yu et al., 2003; Long et al., 2008; Kiran et al., 2009a,b; Pan et al., 2011; Han et al., 2012; $\mathrm{Li}$ et al., 2012). However, the association between the c.1471G $>$ A polymorphism in XRCC1 and HCC susceptibility has not been investigated. The purpose of this study was to evaluate whether the XRCC1 c.1471G $>$ A polymorphism influences the susceptibility to HCC in the Chinese population.

\section{MATERIAL AND METHODS}

\section{Subjects}

Patients with HCC (460) and non-cancer controls (463) were recruited from January 2010 to December 2011 in the Yiwu Central Hospital. All subjects were unrelated Han Chinese. Clinical characteristics, including gender, age, alcohol drinking, tobacco smoking, hypertension, diabetes mellitus, family history of HCC, HBV serological markers, and serum a-FP levels are summarized in Table 1 . The protocol for this study was approved by the local Ethics Committee, and all subjects signed an informed consent form.

\section{XRCC1 polymorphism genotyping}

Genomic DNA was extracted from peripheral venous blood using the standard phenol/chloroform extraction method. Primers were designed based on the DNA and mRNA sequences of human XRCC1 (GenBank IDs: NC_000019.9 and NM_006297.2) using the Primer Premier 5.0 software. Primers, annealing temperature, region, fragment sizes, and selected 
restriction enzymes (MBI Fermentas, St. Leon-Rot, Germany) are shown in Table 2. Genotyping was accomplished by the created restriction site-polymerase chain reaction (CRS-PCR) method, with one of the primers containing a nucleotide mismatch. This enabled the use of restriction enzymes for discriminating sequence variations (Yuan et al., 2012, 2013a,b). PCRs were performed in a total volume of $20 \mu \mathrm{L}$ containing $50 \mathrm{ng}$ template DNA, $1 \mathrm{X}$ buffer (100 $\mathrm{mM}$ Tris- $\mathrm{HCl}, \mathrm{pH} 8.3,500 \mathrm{mM} \mathrm{KCl}), 0.25 \mu \mathrm{M}$ primers, $2.0 \mathrm{mM} \mathrm{MgCl}, 0.25 \mathrm{mM}$ dNTPs, and 0.5 U Taq DNA polymerase (Promega, Madison, WI, USA). PCR conditions were as follows: initial denaturation at $94^{\circ} \mathrm{C}$ for $5 \mathrm{~min}$, followed by 35 cycles at $94^{\circ} \mathrm{C}$ for $30 \mathrm{~s}, 64^{\circ} \mathrm{C}$ for $30 \mathrm{~s}, 72^{\circ} \mathrm{C}$ for $30 \mathrm{~s}$, and a final extension at $72^{\circ} \mathrm{C}$ for $5 \mathrm{~min}$. The PCR amplified products were digested with $2 \mathrm{U}$ restriction enzyme (shown in Table 2 ) at $37^{\circ} \mathrm{C}$ for $10 \mathrm{~h}$, electrophoresed on a $3 \%$ agarose gel, and visualized under UV light.

\section{Statistical analysis}

All statistical analyses were performed using the Statistical Package for Social Sciences software (SPSS, Windows version, release 15.0; SPSS Inc., Chicago, IL, USA). The chi-squared $\left(\chi^{2}\right)$ test was used to evaluate Hardy-Weinberg equilibrium, allele and genotype frequencies, and general characteristics of healthy controls and HCC patients. Associations between allele and genotype frequencies and HCC susceptibility were estimated using the odds ratios (ORs) with their $95 \%$ confidence intervals (CIs). A P value $<0.05$ was defined as statistically significant.

\section{RESULTS}

\section{General characteristics of the subjects}

In this case-control study, 923 Chinese subjects were enrolled, including $460 \mathrm{HCC}$ cases and 463 healthy controls. The general characteristics of the subjects are shown in Table 1. There was no significant difference between cases and controls with regard to gender and age $(\mathrm{P}=0.4426$ and $\mathrm{P}=0.3363$, respectively). Additionally, no significant differences were found in alcohol drinking, tobacco smoking, hypertension, or diabetes mellitus between case and control groups $(\mathrm{P}=0.3700, \mathrm{P}=0.4816, \mathrm{P}=0.4252$, and $\mathrm{P}=0.2605$, respectively).

\section{Identification and genotyping of the $X R C C 1$ polymorphism}

A novel allelic variant (c.1471G $>$ A) was identified by CRS-PCR and DNA-sequencing methods. Sequence analysis revealed a G to A mutation in exon 13 of the XRCC1 gene, resulting in a glutanine (Glu) to lysine (Lys) amino acid substitution (p.Glu491Lys, reference sequences GenBank IDs: NC_000019.9, NM_006297.2 and NP_006288.2). PCR products were digested with $A l w$ NI restriction enzyme and divided into three genotypes, based on restriction fragment pattern: GG (194 and $21 \mathrm{bp})$, GA (215, 194 and $21 \mathrm{bp})$ and AA (215 bp). Results are shown in Table 2. The allele and genotype frequency distributions in both HCC patients and healthy controls are summarized in Table 3. The allele frequencies of HCC patients $(\mathrm{G}=58.15 \% ; \mathrm{A}=41.85 \%)$ were significantly different from healthy controls $(\mathrm{G}=$ $67.28 \% ; \mathrm{A}=32.72 \% ; \chi^{2}=16.4413, \mathrm{P}<0.0001$; Table 3 ). In addition, significant differences 
in genotype frequencies between cases and controls were found $\left(\chi^{2}=16.0887 ; \mathrm{P}=0.0003\right.$; Table 3 ). The genotype distributions in the studied subjects did not significantly deviate from Hardy-Weinberg equilibrium (for case group: $\chi^{2}=4.8066, \mathrm{P}=0.0904$; for control group: $\chi^{2}=$ $0.5234, \mathrm{P}=0.7697)$. Results are presented in Table 3 .

Table 1. Clinical characteristics of the hepatocellular carcinoma (HCC) cases and controls.

\begin{tabular}{|c|c|c|c|c|c|c|}
\hline Characteristics & Cases (N) & $\%$ & Controls (N) & $\%$ & $\chi^{2}$ value & P value \\
\hline Number & 460 & & 463 & & & \\
\hline Gender & & & & & 0.5895 & 0.4426 \\
\hline Male & 312 & 67.83 & 303 & 65.44 & & \\
\hline Female & 148 & 32.17 & 160 & 34.56 & & \\
\hline Age (years) & \multirow{2}{*}{\multicolumn{2}{|c|}{$57.23 \pm 12.55$}} & & & 0.9244 & 0.3363 \\
\hline mean $\pm \mathrm{SD}$ & & & \multicolumn{2}{|c|}{$56.43 \pm 13.68$} & & \\
\hline$<55$ & 282 & 61.30 & 298 & 64.36 & & \\
\hline$\geq 55$ & 178 & 38.70 & 165 & 35.64 & & \\
\hline Alcohol drinking & & & & & 0.8038 & 0.3700 \\
\hline Yes & 251 & 54.57 & 239 & 51.62 & & \\
\hline No & 209 & 45.43 & 224 & 48.38 & & \\
\hline Tobacco smoking & & & & & 0.4951 & 0.4816 \\
\hline Yes & 257 & 55.87 & 248 & 53.56 & & \\
\hline No & 203 & 44.13 & 215 & 46.44 & & \\
\hline Hypertension & & & & & 0.6359 & 0.4252 \\
\hline Yes & 63 & 13.70 & 72 & 15.55 & & \\
\hline No & 397 & 86.30 & 391 & 84.45 & & \\
\hline Diabetes mellitus & & & & & 1.2661 & 0.2605 \\
\hline Yes & 79 & 17.17 & 67 & 14.47 & & \\
\hline No & 381 & 82.83 & 396 & 85.53 & & \\
\hline \multicolumn{7}{|c|}{ Family history of HCC } \\
\hline Yes & 23 & 5.00 & - & & & \\
\hline No & 437 & 95.00 & - & & & \\
\hline \multicolumn{7}{|c|}{ HBV serological markers } \\
\hline $\mathrm{HBs} \mathrm{Ag}(+)$ & 126 & 27.39 & - & & & \\
\hline HBs Ag(-) & 334 & 72.61 & - & & & \\
\hline \multicolumn{7}{|l|}{ Serum a-FP levels } \\
\hline$<400 \mathrm{ng} / \mathrm{mL}$ & 156 & 33.91 & - & & & \\
\hline$>400 \mathrm{ng} / \mathrm{mL}$ & 304 & 66.09 & - & & & \\
\hline
\end{tabular}

Table 2. Primer and CRS-PCR analysis used for detecting the $X R C C 1$ gene c. $1471 \mathrm{G}>\mathrm{A}$ polymorphism.

\begin{tabular}{|c|c|c|c|c|c|}
\hline Primer sequences & $\begin{array}{l}\text { Annealing temperature } \\
\qquad\left({ }^{\circ} \mathrm{C}\right)\end{array}$ & $\begin{array}{l}\text { Amplification } \\
\text { fragment (bp) }\end{array}$ & Region & $\begin{array}{l}\text { Restriction } \\
\text { enzyme }\end{array}$ & Genotype (bp) \\
\hline $\begin{array}{l}\text { 5'-AAGATTCTGGGGACACAGAGGČT-3' } \\
\text { 5'-GTGTTCTCATCCGTGGAGCCTG-3' }\end{array}$ & 64.0 & 215 & Exon 13 & $A l w \mathrm{NI}$ & $\begin{array}{l}\text { GG: } 194,21 \\
\text { GA: } 215,194,21 \\
\text { AA: } 215\end{array}$ \\
\hline
\end{tabular}

CRS-PCR $=$ created restriction site-polymerase chain reaction.

Table 3. Genotype and allele frequencies of the $X R C C 1 \mathrm{c} .1471 \mathrm{G}>\mathrm{A}$ polymorphism in cases and controls.

\begin{tabular}{|c|c|c|c|c|c|c|c|c|c|c|c|c|}
\hline \multirow[t]{2}{*}{ Groups } & \multicolumn{6}{|c|}{ Genotype frequencies } & \multicolumn{4}{|c|}{ Allele frequencies } & \multirow[t]{2}{*}{$\chi^{2}$} & \multirow[t]{2}{*}{$\mathrm{P}$} \\
\hline & GG & $\%$ & GA & $\%$ & $\mathrm{AA}$ & $\%$ & G & $\%$ & A & $\%$ & & \\
\hline Cases $(\mathrm{N}=460)$ & 167 & 36.30 & 201 & 43.70 & 92 & 20.00 & 535 & 58.15 & 385 & 41.85 & 4.8066 & 0.0904 \\
\hline Controls $(\mathrm{N}=463)$ & 213 & 46.00 & 197 & 42.55 & 53 & 11.45 & 623 & 67.28 & 303 & 32.72 & 0.5234 & 0.7697 \\
\hline \multirow[t]{2}{*}{ Total $(\mathrm{N}=923)$} & 380 & 41.17 & 398 & 43.12 & 145 & 15.71 & 1158 & 62.73 & 688 & 37.27 & 5.5890 & 0.0611 \\
\hline & \multicolumn{6}{|c|}{$\chi^{2}=16.0887, \mathrm{P}=0.0003$} & \multicolumn{4}{|c|}{$\chi^{2}=16.4413, \mathrm{P}<0.0001$} & & \\
\hline
\end{tabular}




\section{XRCC1 polymorphism and HCC susceptibility}

As shown in Table 4, alleles and genotypes of the c.1471G>A polymorphism were significantly associated with HCC susceptibility. There was significantly increased susceptibility to $\mathrm{HCC}$ in the homozygote comparison (AA $v s \mathrm{GG}$ : $\mathrm{OR}=2.214,95 \% \mathrm{CI}=1.493-3.283$, $\left.\chi^{2}=15.97, \mathrm{P}=0.0001\right)$, dominant model (AA+GA $v s \mathrm{GG}: \mathrm{OR}=1.495,95 \% \mathrm{CI}=1.148-1.946$, $\left.\chi^{2}=12.75, \mathrm{P}=0.0004\right)$, recessive model (AA $v s \mathrm{GA}+\mathrm{GG}: \mathrm{OR}=1.934,95 \% \mathrm{CI}=1.341-2.789$, $\left.\chi^{2}=8.96, \mathrm{P}=0.0028\right)$, and allele contrast (A vs $\mathrm{G}: \mathrm{OR}=1.480,95 \% \mathrm{CI}=1.224-1.789, \chi^{2}=$ $16.44, \mathrm{P}=0.0001$ ), while a marginal significance was found in heterozygote comparison (GA $v_{s} \mathrm{GG}: \mathrm{OR}=1.301,95 \% \mathrm{CI}=0.981-1.726, \chi^{2}=3.35, \mathrm{P}=0.0672$; Table 4).

\begin{tabular}{|c|c|c|c|}
\hline Comparisons & OR $(95 \% \mathrm{CI})$ & $\chi^{2}$ value & P value \\
\hline Homozygote comparison (AA vs GG) & $2.214(1.493-3.283)$ & 15.97 & 0.0001 \\
\hline Heterozygote comparison (GA vs $\mathrm{GG}$ ) & $1.301(0.981-1.726)$ & 3.35 & 0.0672 \\
\hline Dominant model (AA/GA vs GG) & $1.495(1.148-1.946)$ & 12.75 & 0.0004 \\
\hline Recessive model (AA vs GA/GG) & $1.934(1.341-2.789)$ & 8.96 & 0.0028 \\
\hline Allele contrast (A vs $\mathrm{G})$ & $1.480(1.224-1.789)$ & 16.44 & 0.0001 \\
\hline
\end{tabular}

SNPs $=$ single nucleotide polymorphisms; $\mathrm{OR}=$ odds ratio; $95 \% \mathrm{CI}=95 \%$ confidence interval.

\section{DISCUSSION}

HCC is a common malignant tumor resulting from complex interactions between multiple environmental and genetic factors (Marrero et al., 2005; Farazi and DePinho, 2006; El-Serag and Rudolph, 2007; Amarapurkar et al., 2008). Previous studies suggested that environmental risk factors, including cigarette smoking, alcohol consumption, chronic hepatitis $\mathrm{B}$ or hepatitis $\mathrm{C}$ viral infections, and exposure to dietary aflatoxin B1 (AFB1), are associated with HCC (Bosch et al., 2004; Suriawinata and Xu, 2004; Farazi and DePinho, 2006; Gomaa et al., 2008). Furthermore, it is generally accepted that genetic factors play a key role in the pathogenesis of HCC (Thorgeirsson and Grisham, 2002; Nault and Zucman-Rossi, 2011). Several studies have evaluated how Arg194Trp, Arg280His and Arg399Gln polymorphisms in XRCC1 affect the risk of HCC (Rossit et al., 2002; Yu et al., 2003; Long et al., 2008; Kiran et al., 2009a,b; Pan et al., 2011; Han et al., 2012; Li et al., 2012), but with conflicting rather than conclusive results. In this study, we firstly evaluated the association between the XRCC1 c. $1471 \mathrm{G}>\mathrm{A}$ polymorphism and susceptibility to HCC in the Chinese Han population. Our results indicate that the AA genotype was strongly associated with increased susceptibility to developing HCC compared with the GG genotype and GA/GG carriers $(\mathrm{P}=0.0001$ and $\mathrm{P}=$ 0.0028). Using GG as the reference genotype, the AA/GA carriers had increased susceptibility to HCC $(\mathrm{P}=0.0004)$. The A allele may contribute to the susceptibility to HCC $(\mathrm{P}=0.0001$; Table 4). Our data indicate that the $X R C C 1 \mathrm{c} .1471 \mathrm{G}>\mathrm{A}$ polymorphism is associated with increased susceptibility to HCC in the Chinese population.

In conclusion, to the best of our knowledge, this is the first investigation of the association between the XRCC1 c.1471G $>$ A polymorphism and HCC susceptibility. Results from this study provide additional evidence of the role of XRCC1 in HCC susceptibility. The 
c. $1471 \mathrm{G}>$ A polymorphism in $X R C C 1$ could be a useful molecular marker for evaluating susceptibility to HCC. Further investigations on larger populations are needed to confirm these results and to explain the role of the c. $1471 \mathrm{G}>$ A polymorphism and other XRCC1 polymorphisms in susceptibility to HCC.

\section{Conflicts of interest}

The authors declare no conflict of interest.

\section{REFERENCES}

Amarapurkar DN, Patel ND and Kamani PM (2008). Impact of diabetes mellitus on outcome of HCC. Ann. Hepatol. 7: 148-151.

Borentain P, Gerolami V, Ananian P, Garcia S, et al. (2007). DNA-repair and carcinogen-metabolising enzymes genetic polymorphisms as an independent risk factor for hepatocellular carcinoma in Caucasian liver-transplanted patients. Eur. J. Cancer 43: 2479-2486.

Bosch FX, Ribes J, Diaz M and Cleries R (2004). Primary liver cancer: worldwide incidence and trends. Gastroenterology 127: S5-S16.

But DY, Lai CL and Yuen MF (2008). Natural history of hepatitis-related hepatocellular carcinoma. World J. Gastroenterol. 14: 1652-1656.

Chen CC, Yang SY, Liu CJ, Lin CL, et al. (2005). Association of cytokine and DNA repair gene polymorphisms with hepatitis B-related hepatocellular carcinoma. Int. J. Epidemiol. 34: 1310-1318.

Chen JG, Zhang SW and Chen WQ (2010). Analysis of liver cancer mortality in the national retrospective sampling survey of death causes in China, 2. Zhonghua YuFang YiXue ZaZhi 44: 383-389.

El-Serag HB and Rudolph KL (2007). Hepatocellular carcinoma: epidemiology and molecular carcinogenesis. Gastroenterology 132: 2557-2576.

Farazi PA and DePinho RA (2006). Hepatocellular carcinoma pathogenesis: from genes to environment. Nat. Rev. Cancer 6: 674-687.

Gomaa AI, Khan SA, Toledano MB, Waked I, et al. (2008). Hepatocellular carcinoma: epidemiology, risk factors and pathogenesis. World J. Gastroenterol. 14: 4300-4308.

Han X, Xing Q, Li Y, Sun J, et al. (2012). Study on the DNA repair gene XRCC1 and XRCC3 polymorphism in prediction and prognosis of hepatocellular carcinoma risk. Hepatogastroenterology 59.

Kiran M, Chawla YK, Jain M and Kaur J (2009a). Haplotypes of microsomal epoxide hydrolase and x-ray crosscomplementing group 1 genes in Indian hepatocellular carcinoma patients. DNA Cell Biol. 28: 573-577.

Kiran M, Saxena R, Chawla YK and Kaur J (2009b). Polymorphism of DNA repair gene XRCC1 and hepatitis-related hepatocellular carcinoma risk in Indian population. Mol. Cell. Biochem. 327: 7-13.

Kirk GD, Turner PC, Gong Y, Lesi OA, et al. (2005). Hepatocellular carcinoma and polymorphisms in carcinogenmetabolizing and DNA repair enzymes in a population with aflatoxin exposure and hepatitis B virus endemicity. Cancer Epidemiol. Biomarkers Prev. 14: 373-379.

Li QW, Lu CR, Ye M, Xiao WH, et al. (2012). Evaluation of DNA repair gene XRCC1 polymorphism in prediction and prognosis of hepatocellular carcinoma risk. Asian Pac. J. Cancer Prev. 13: 191-194.

Liu F, Li B, Wei Y, Yan L, et al. (2011). XRCC1 genetic polymorphism Arg399Gln and hepatocellular carcinoma risk: a meta-analysis. Liver Int. 31: 802-809.

Llovet JM, Burroughs A and Bruix J (2003). Hepatocellular carcinoma. Lancet 362: 1907-1917.

Long XD, Ma Y, Wei YP and Deng ZL (2006). The polymorphisms of GSTM1, GSTT1, HYL1*2, and XRCC1, and aflatoxin B1-related hepatocellular carcinoma in Guangxi population, China. Hepatol. Res. 36: 48-55.

Long XD, Ma Y, Huang HD, Yao JG, et al. (2008). Polymorphism of XRCC1 and the frequency of mutation in codon 249 of the p53 gene in hepatocellular carcinoma among Guangxi population, China. Mol. Carcinog. 47: 295-300.

Marrero JA, Fontana RJ, Fu S, Conjeevaram HS, et al. (2005). Alcohol, tobacco and obesity are synergistic risk factors for hepatocellular carcinoma. J. Hepatol. 42: 218-224.

Nault JC and Zucman-Rossi J (2011). Genetics of hepatobiliary carcinogenesis. Semin. Liver Dis. 31: 173-187.

Pan HZ, Liang J, Yu Z, Lun LM, et al. (2011). Polymorphism of DNA repair gene XRCC1 and hepatocellular carcinoma risk in Chinese population. Asian Pac. J. Cancer Prev. 12: 2947-2950. 
Parikh S and Hyman D (2007). Hepatocellular cancer: a guide for the internist. Am. J. Med. 120: 194-202.

Parkin DM (2001). Global cancer statistics in the year 2000. Lancet Oncol. 2: 533-543.

Parkin DM, Bray F, Ferlay J and Pisani P (2005). Global cancer statistics, 2002. CA Cancer J. Clin. 55: 74-108.

Rossit AR, Cabral IR, Hackel C, da Silva RC, et al. (2002). Polymorphisms in the DNA repair gene XRCC1 and susceptibility to alcoholic liver cirrhosis in older Southeastern Brazilians. Cancer Lett. 180: 173-182.

Schutte K, Bornschein J and Malfertheiner P (2009). Hepatocellular carcinoma - epidemiological trends and risk factors. Dig. Dis. 27: 80-92.

Suriawinata A and Xu R (2004). An update on the molecular genetics of hepatocellular carcinoma. Semin. Liver Dis. 24: 77-88.

Thorgeirsson SS and Grisham JW (2002). Molecular pathogenesis of human hepatocellular carcinoma. Nat. Genet. 31: 339-346.

Yu MW, Yang SY, Pan IJ, Lin CL, et al. (2003). Polymorphisms in XRCC1 and glutathione S-transferase genes and hepatitis B-related hepatocellular carcinoma. J. Natl. Cancer Inst. 95: 1485-1488.

Yuan Z, Li J, Li J, Zhang L, et al. (2012). Investigation on BRCA1 SNPs and its effects on mastitis in Chinese commercial cattle. Gene 505: 190-194.

Yuan Z, Li J, Li J, Gao X, et al. (2013a). SNPs identification and its correlation analysis with milk somatic cell score in bovine MBL1 gene. Mol. Biol. Rep. 40: 7-12.

Yuan Z, Li J, Li J, Gao X, et al. (2013b). Effects of DGAT1 gene on meat and carcass fatness quality in Chinese commercial cattle. Mol. Biol. Rep. 40: 1947-1954.

Yuen MF, Hou JL and Chutaputti A (2009). Hepatocellular carcinoma in the Asia pacific region. J. Gastroenterol. Hepatol. 24: 346-353. 